\title{
Interpretation of Structural Terrace of Sheets: 303, 304 and 305 using Geophysical Attributes in Parts of Bamenda Massif, Southeastern Nigeria
}

\author{
Rorome Oghonyon $^{1} \&$ Kiamuke Itiowe ${ }^{2 *}$ \\ ${ }^{I}$ Department of Geology, University of Port Harcourt, Port Harcourt, Rivers State, Nigeria. \\ ${ }^{2}$ Department of Earth Sciences, Arthur Jarvis University, Akpabuyo, Cross River State, Nigeria. \\ Corresponding Author Email: kiamukeitiowe@yahoo.com ${ }^{2 *}$
}

Copyright: @ 2021 Rorome Oghonyon \& Kiamuke Itiowe. This is an open access article distributed under the terms of the Creative Commons Attribution License, which permits unrestricted use, distribution, and reproduction in any medium, provided the original author and source are credited.

\section{ABSTRACT}

The study on interpretation of aeromagnetic data of parts of Bamenda Massif (sheet 303, 304, and 305) South-eastern Nigeria has been evaluated. The data sets used are digitized maps of aeromagnetic data. The study area was characterized into four distinct zones such as $A, B, C$ and $D$. Zone $A$ occur in the northern portion and it is characterized by linear anomaly of amplitude $66.2-98.5 n T$. Zone $B$ and C primarily share the same structural grain connecting the southwest and southern portions of the study area where they are characterised with large "bull eye" and narrow shaped anomalies. Zone D occupies the western and central portions of the study area showing features of magnetic highs and lows due to sporadic intrusions. The analysis review lineament structures aligned in a NE-SW and NW-SE trends which is in similar pattern to the initial rifting of the southern Nigerian margin system. Zone A, B and C are bound by intrusives of igneous origin. However, the interconnectivity of the structural lineaments makes them stand out as pathways for mineralization. Thus, most of the lineaments are believed to be located at a depth range of $<246.5 \mathrm{~m}$ to $258.2 \mathrm{~m}, 258.2 \mathrm{~m}$ to $437 \mathrm{~m}, 212.9 \mathrm{~m}$ to $>626.1 \mathrm{~m}$ and $769.2 \mathrm{~m}$ to $1039.7 \mathrm{~m}$ within the subsurface rocks.

Keywords: Aeromagnetic data, Bamenda Massif, Structural, anomalies, Mineralization.

\section{Introduction}

Perhaps, aeromagnetic geophysical method plays a distinguished role when compared with other geophysical methods in its rapid rate of coverage and low cost per unit area explored. In many sedimentary basins, magnetic anomalies arise from secondary mineralization along fracture planes or fault zones, tectonic contact, etc., which are often revealed on aeromagnetic maps as linear features [1, 2, 3]. Hence, the study uses aeromagnetic and geological data to provide new interpretations (map and section-view) of crustal architecture in parts of Bamenda Massif, South-eastern Nigeria. Different forms of the geophysical methods can be used for extraction of geological properties from subsurface rocks, depending on the conditions and manner of surveying: borehole, airborne, ground etc. Each of these forms has its methodical, instrumental and interpretational peculiarities [4]. In this respect, geophysical data are among one of parameters that contribute to the description of rock properties and their structural relationships. By evaluating such parameters in regard to other known data, both the geologists and geophysicists acquire new insights into the exploration challenges to be solved. This approach may seem obvious, but in practice is seldom applied [5].

\subsection{Geologic setting of the study area}

The Basement complex of the eastern part of Nigeria constitutes of three significant megastructural features that show the exposure of the Precambrian basement complex. They are: the Bemenda, Oban and Hawal Massifs [6]. Each of these massifs has some peculiarities unique to them. The geology of these massifs is characterized by high-grade basement rocks such as granite-diorites and Pan-African intrusions [[7, 8, 9], and Jurassic alkaline granite, granulite facies gneisses, metaoelite and cal-silicate rock [10, 11, 12, 13, 14]. 
The Bamenda Massif which constitutes section of the Precambrian Pan-African tectonothermal belt, resting between the Gabon-Congo Craton and West African Craton (Fig.1). It is bounded by the Benue Trough, in the NE-SW axis, and the Cameroon volcanic line in the southeast $[15,16,17,18,19,20]$. Basically, parts of Bamenda Massif are composed majorly of high-grade metamorphic rock sequences which show magmatic characteristics, and have been intruded in various areas by major plutonic rocks [21, 22, 23, 24, 25, 26, 27, 28].

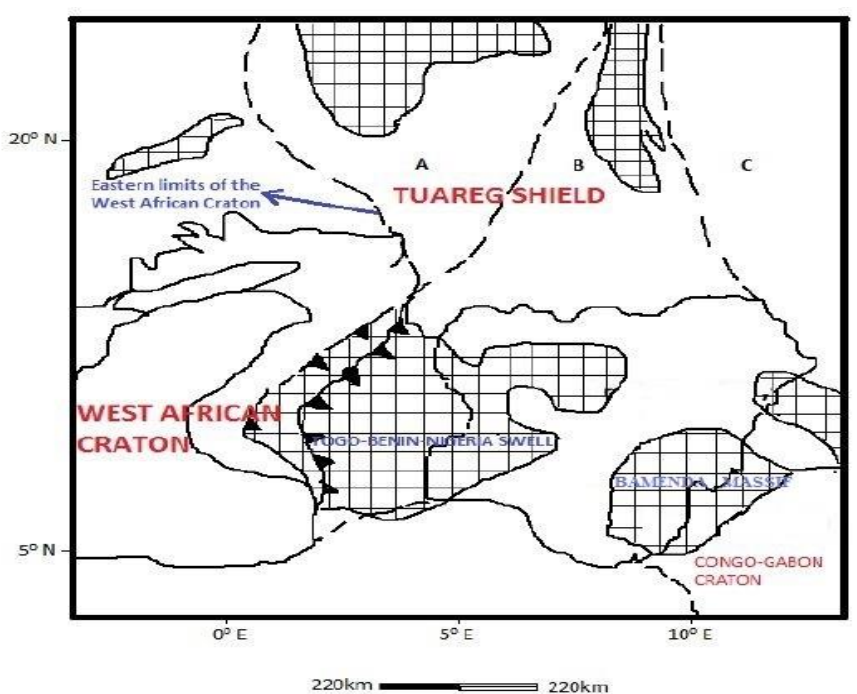

Fig.1. Geological map of parts of West African showing the Bamenda Massif, Pan-African basement, the Congo-Gabon craton and West Africa craton (modified after [29])

The study area is located within latitudes $05^{0} 30^{\prime} 00^{\prime \prime} \mathrm{N}$ to $06^{\circ} 03^{\prime} 00^{\prime \prime} \mathrm{N}$ and longitudes $07^{0} 0^{\prime} 0^{\prime \prime} \mathrm{E}$ to $09^{0} 30^{\prime} 00^{\prime \prime} \mathrm{E}$ (Fig.2). The area of study, Bamenda Massif is considered to be Precambrian in terms of geologic age [30]. The banded gneisses are believed to be the oldest rock in the southeastern Nigeria and the dolerite which is part of the igneous intrusives is the youngest rock in the area. These rock deposits are overlain by Cretaceous -Tertiary sediments [1].

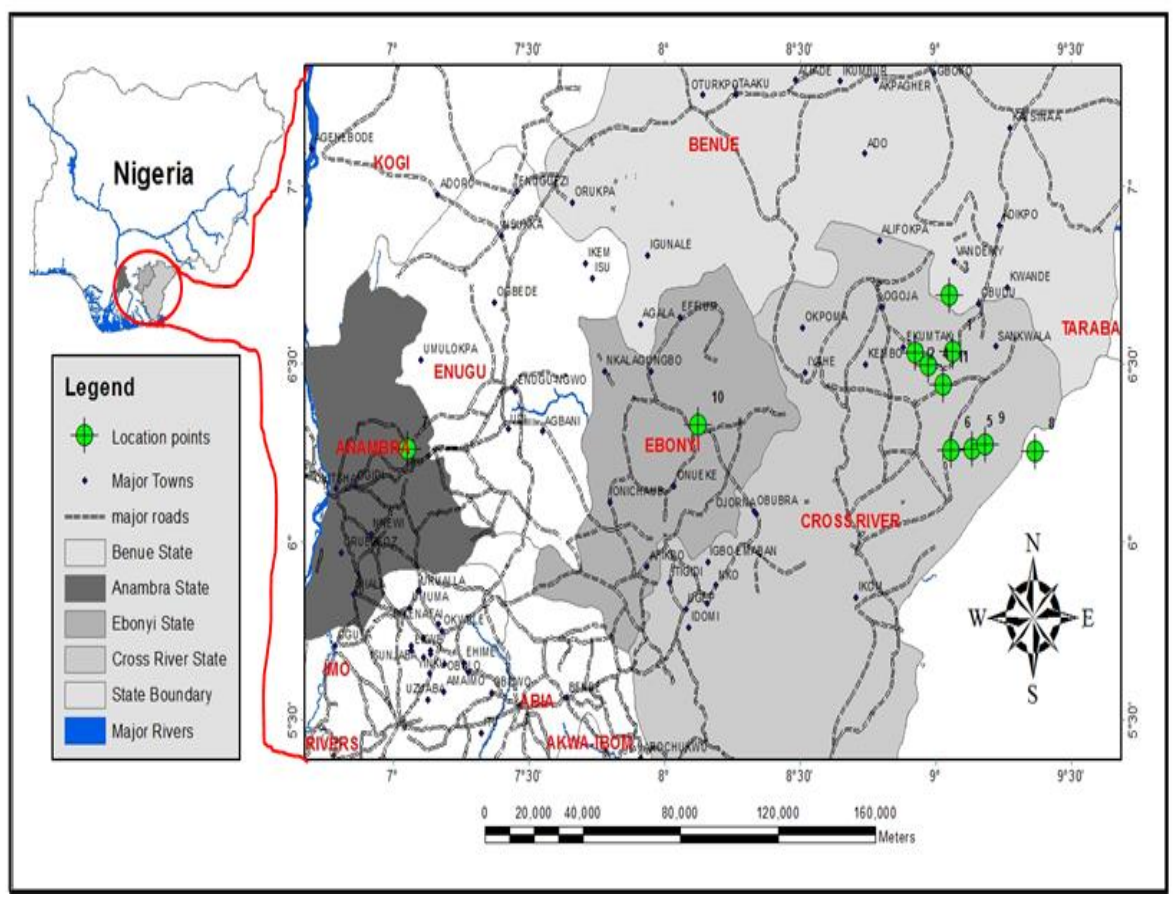

Fig.2. Location map of the study area (Source: GIS software 2017) 


\section{Data set and Methodology}

\subsection{Data set and Source}

The data set used in this research work includes aeromagnetic data (of sheet 303, 304 and 305), the survey covers 128, 180-line kilometers and was obtained from the Nigerian Geological Survey Agency (NGSA) in the scale of 1: 100,000 . However, a digitized geological map was obtained as part of the data from the Nigerian Geologic Survey Agency (NGSA), Abuja, Nigeria. Technical details of the aeromagnetic data include: a Total Lines of 1,104,174km, Flight Line Spacing of 500 meters, Terrain Clearance of 80 meters, Flight Line Direction in NW-SE, Tie Line Spacing of $2 \mathrm{~km}$ and Tie Line Direction in NE-SW.

\subsection{Method/Data Processing}

The grid data was analysed using Oasis Montaj Geosoft in a grid file format. Line data are delivered in Oasis Montaj Geosoft format and ASCII file format and a format description file accompanies each data file. Clearly, the data processing involves accurate enhancement of the short-wavelength and linear features. In that regard, the aeromagnetic data was first re-gridded with a grid-cell spacing of $200 \mathrm{~m}$ and was subjected to regional/residual separation to isolate short-wavelength signals which are more suitable for high-resolution mapping of shallow magnetic anomalies from long-broad wavelength signals.

The regional/residual separation was made by upward continuation of the total magnetic intensity aeromagnetic grid. In this way, the upward continuation transformation attenuates the high-frequency signal components and therefore, tends to emphasize deep, regional-scale magnetic anomalies. Subtraction of the low-frequency upward-continued data from the original grid produces a residual map that is enhanced in the short-wavelength signal.

The enhancement of magnetic anomalies that are associated with faults and other structural discontinuities were achieved by the application of FVD to the residual map in figure 7 and 8 [31, 32, 33, 34]. The reprocessed aeromagnetic data set is significantly enhanced in high frequencies and is much better suited to detailed regional shallow mapping and analysis of basement magnetic boundaries.

\subsection{Aeromagnetic Data Analysis}

Derivatives tend to sharpen the edges of anomalies and enhance shallow features. The vertical derivative map is much more responsive to local influences than to broad or regional effects and therefore tends to give sharper picture than the map of the total field intensity.

Thus, the smaller anomalies are clearer in area of strong regional disturbances. In fact, the FVD is used to delineate high frequency features more clearly where they are shadowed by large amplitude, low frequency anomalies [35].

\subsection{Euler Deconvolution}

The objective of the Euler deconvolution process is to determine the shape and corresponding depth estimations of geologic sources of magnetic and anomalies along profiles [36, 37]. Thus, Euler deconvolution can be applied to profiles and therefore, assume that the field is symmetrically transverse to the profiles. However, the total field can 
be the sum of a regional field and the anomaly due to the point source [36,37]. The focus of the Euler analysis is on the constraining of the depth of perturbing body responsible for the regional anomalies.

\subsection{Geophysical Attributes vis-à-vis Structural Terrace}

Structural terrace from outcrops proves fundamental understanding of different structural imprints that are embedded within the basement rocks due to subsurface activities in the study area. These structures are characterized by geological processes such as volcanism, tectonism and magmatism. The resultant of these processes gave rise to large and small scale structural features such as lineaments, faults, joints and fissures within the basement rocks and the sedimentary cover.

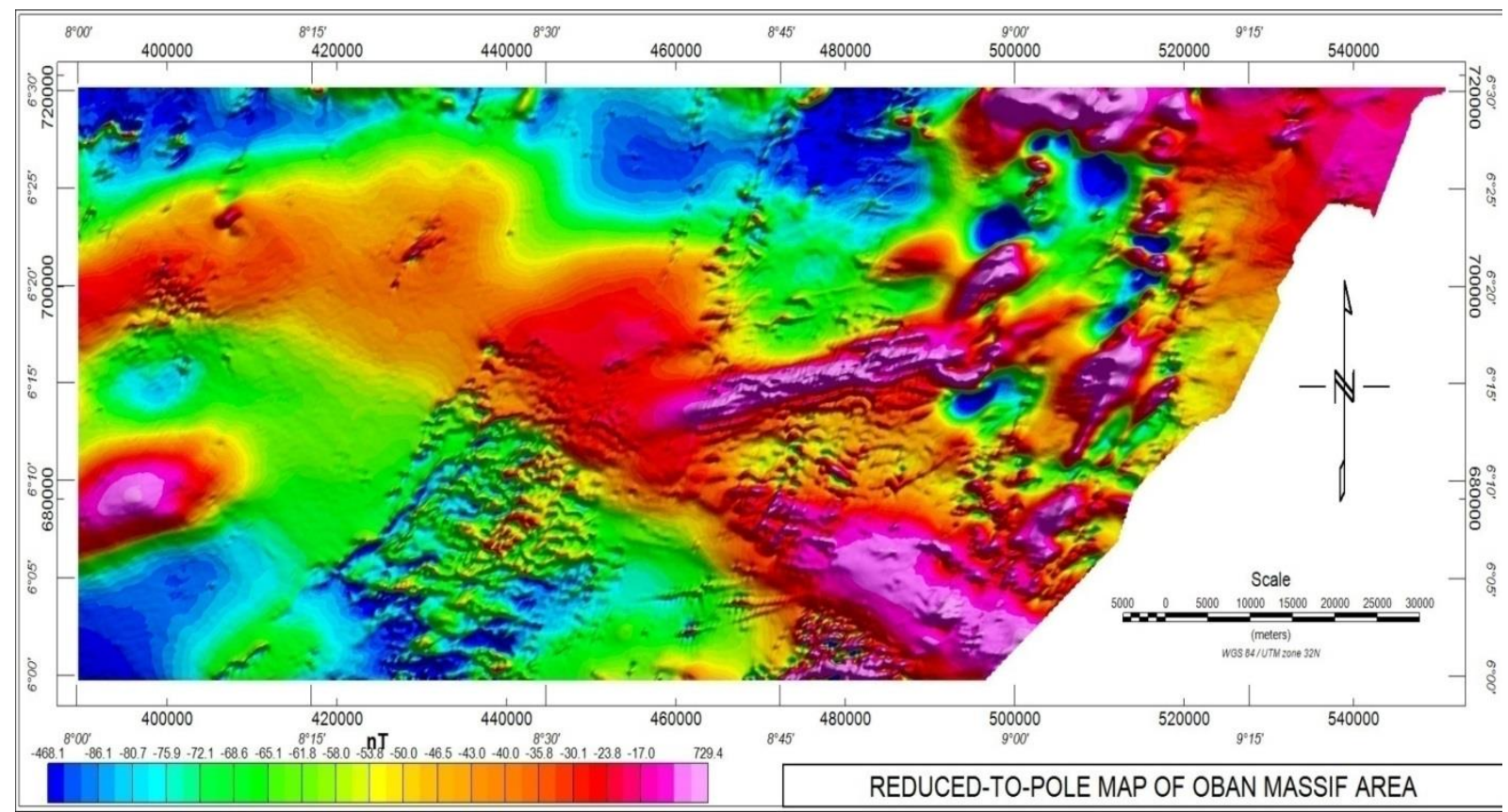

Fig.3. Reduced-to-pole map

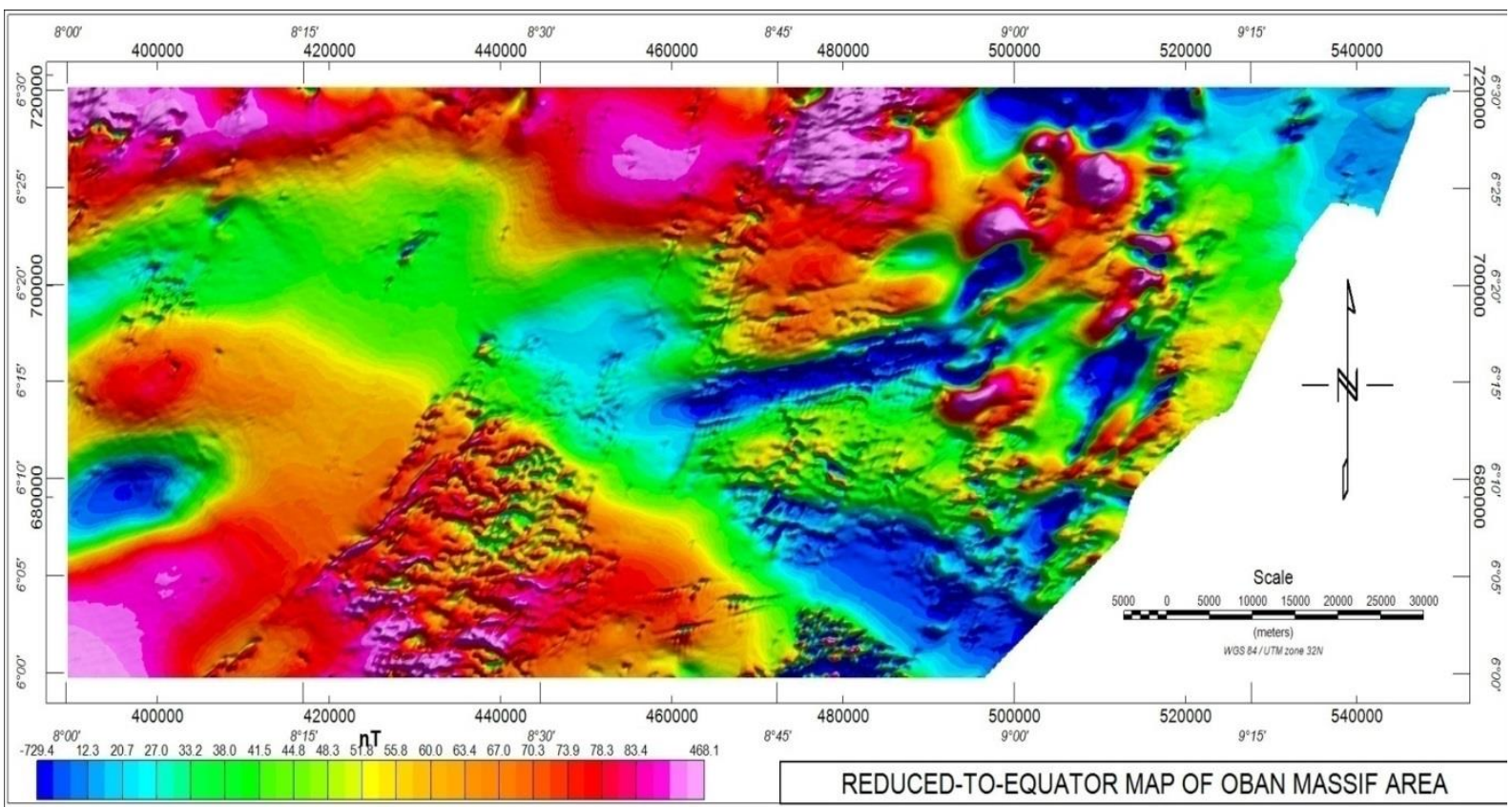

Fig.4. Reduced to equator map 


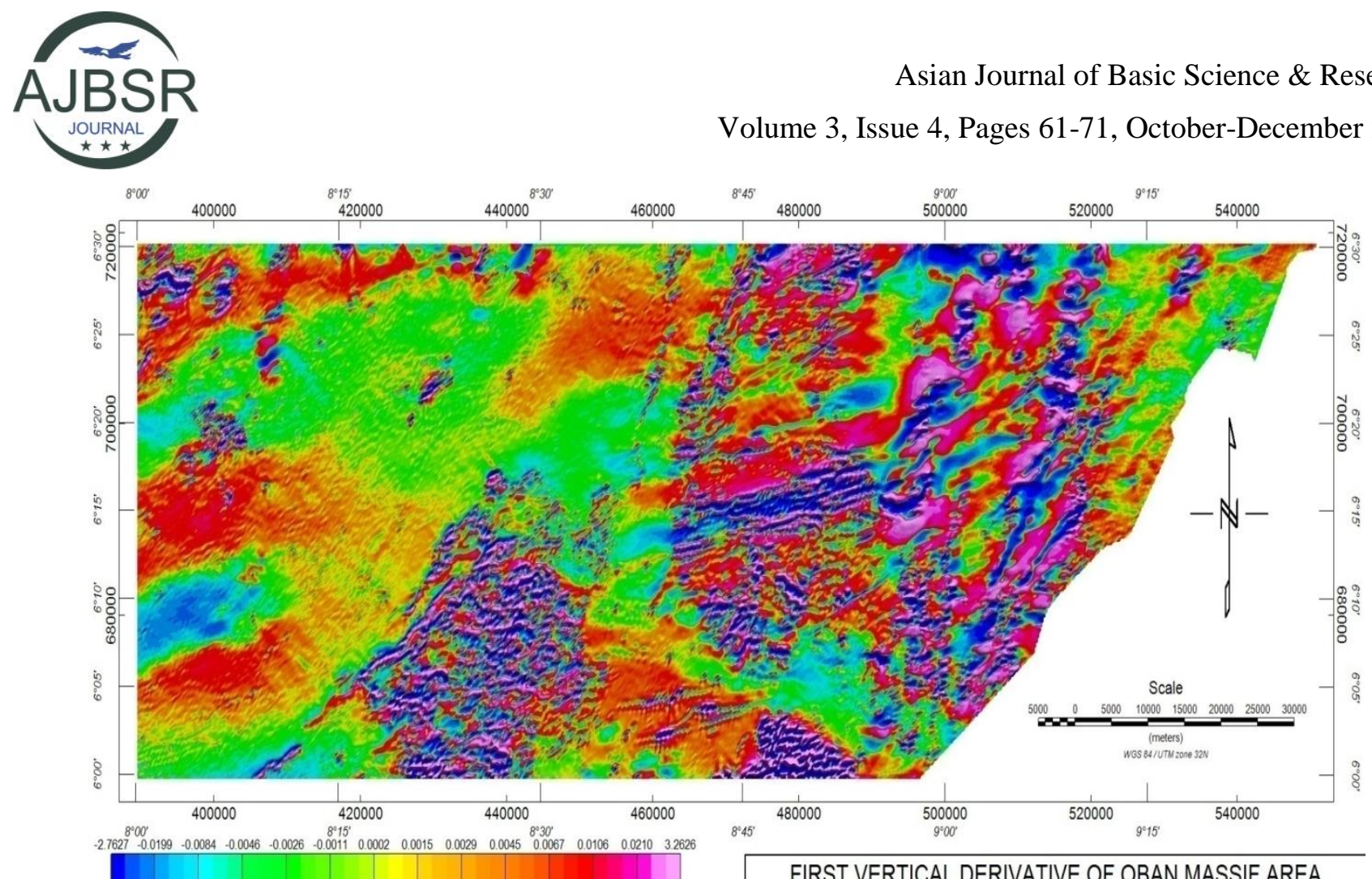

Fig.5. First vertical derivative map
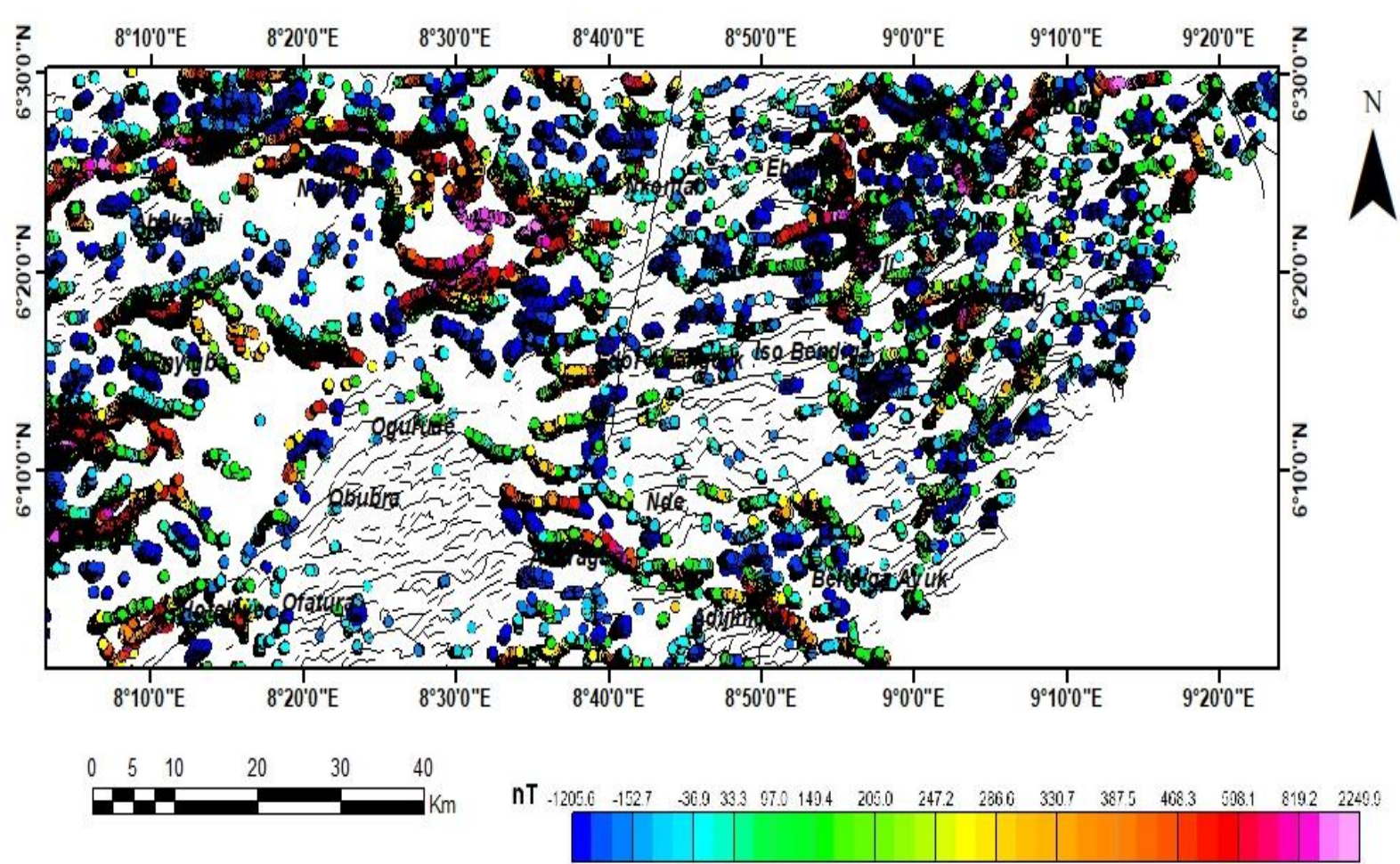

Fig.6. Lineament trends superimposed on Euler deconvolution map

The processing of the data resulted to a 'reduced to pole' map which demonstrates lineaments that are striking in different directions with respect to the zones of magnetic intensities in the area (Fig.3). The 'reduced to equator' map that enables an improve resolution property of the structural features existing within the rocks (Fig.4). The map shows structural lineaments striking in the NE-SW and NW-SE trends. Although, the dominant trend of the structural lineament is in the NE-SW direction. These structural features lineaments and faults are openings for mineralization at depth and can be interpreted as anomalous zones within the basement rocks (Figs.3 and 4). 
The first vertical derivative map was obtained at the processing of the data using Oasis Montaj software. The map was used to understand the various magnetic anomalous zones and their magnetic intensities with respect to the structures formed in the area (Fig. 5). The map is characterized with lineament and fault structures as possible mineralized zones. Fig. 6 describes the superimposition of structural lineaments on an Euler deconvolution map. This map also reveals that areas like Obubra, Ofatuna, Ogurude, Nde and Abakaliki have more structural lineaments that are dominantly striking in the NE-SW trend. The intensity of these lineaments in this area is an indication of compressional stress acting in the area.

\section{Results and Discussion}

\subsection{Interpretation}

This study demonstrates the use of digitized aeromagnetic maps for mapping and analysing lineaments in the Basement Complex region (Bamenda Massif) of south-eastern Nigeria. Several methods were adopted in the determination of depth to basement surface in this study, as well as, draw and interpret profile lines from magnetic maps (Fig.7). In this way, the depth estimation approach was used to determine magnetic parameters such as amplitude, width of the body, depth to basement surface and anomaly source, dip, magnetic susceptibility, percentage magnetite and to know the possible rock type existing in the four different zones (A, B, C and D) across the study area (Fig.7).

Hence, these magnetic parameters are needed for the characterization of the magnetic anomalies across the zones in relation to the already existing geology at the subsurface area. Indeed, there are intrusive bodies of circular, elliptical, narrow shape and sporadic dikes all over the area due to subsurface movement of basement rocks that is triggered by tectonic and deformational processes which may have caused the north-eastern part to move upthrown relative to the south-western part which moved down thrown (Fig.8).

This in effect, shows several depths to basement surface in the different zones of the study area. However, Zone A has depth estimates in the range of $<246.5 \mathrm{~m}-258.2 \mathrm{~m}$ in areas like Nkonfab and Ebem, probably, due to uplift of subsurface materials. Other area like Abakaliki and Ndubia show greater depth to basement surface of $717.1 \mathrm{~m}$ 1241.2m. Zone B has depth estimates of $769.2 \mathrm{~m}-1039.7 \mathrm{~m}$ and $1039.7 \mathrm{~m}->1317.6 \mathrm{~m}$ in areas like Hotekwe and Enyigba, indicating the down thrown part of the study area. The depth to basement surface and source producing the magnetic anomalous intrusives in this zone is deep seated. Consequently, zone $\mathrm{C}$ shows similar upward movement of basement materials as a reflection of sporadic and narrow dike intrusions, therefore, has depth estimate of $152.3 \mathrm{~m}-274.5 \mathrm{~m}$ in areas like Ofatura and 437m - 769.2m in Abaragba area. While zone D has deep source to basement surface in areas like Kanyang, Boje and Ubong having depth values of $769.2 \mathrm{~m}-1039.7 \mathrm{~m}$ and 1039.7m - > 1317.6m respectively (Fig.6). Some mineral deposits like Lead, Zinc, copper, Tin, Platinum, etc, were observed across shear zones and tectonic contacts in the area; Iron ore deposits were observed in Kanyan (around Mbe Mountain); Fool's Gold, Chalcopyrite and Lead deposits were observed in Abakaliki area; Manganese in Buanchor area and Barite in Irruan (around Afi Mountain) of the study area. Hence, the structural trends of the major structures are in NE-SW directions and the minor structures strike in NW-SE directions due to subsurface deformational activities (Fig.10). 


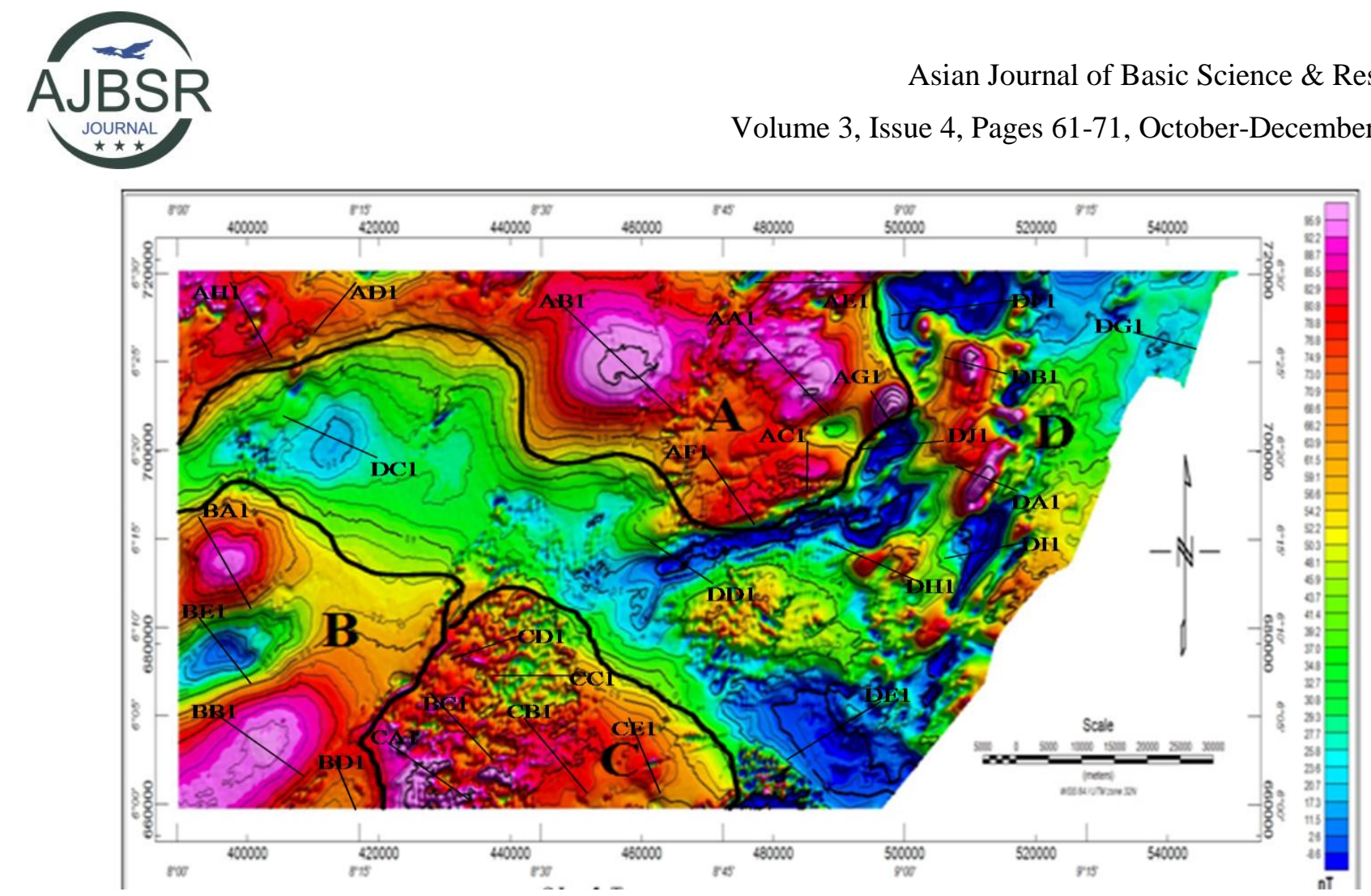

Fig.7. Total magnetic contour map indicating regions of profile lines for graphical magnetic explanation with respect to different zones of magnetic anomalies

\subsection{Structural Modelling}

The 3-D model of Fig.8 shows a superimposed fault model which demonstrates the displacement of the blocks (i.e., hanging and foot wall) on both sides of the fault plain. In this way, the displacement can be observed in a juxtaposed fashion of the reduced to pole aeromagnetic map which shows regions of high and low amplitude of magnetic intensities on different parts of the map. To the right of the reduced to pole aeromagnetic map, there is high magnetic intensity which is because of the intrusive magnetic dykes at the north-eastern part of the 3-D model (Figs.8 and 9). However, this illustrates the up thrown movement of the foot wall and the down thrown movement of the hanging wall (resulting to a normal fault) in the 3-D model.
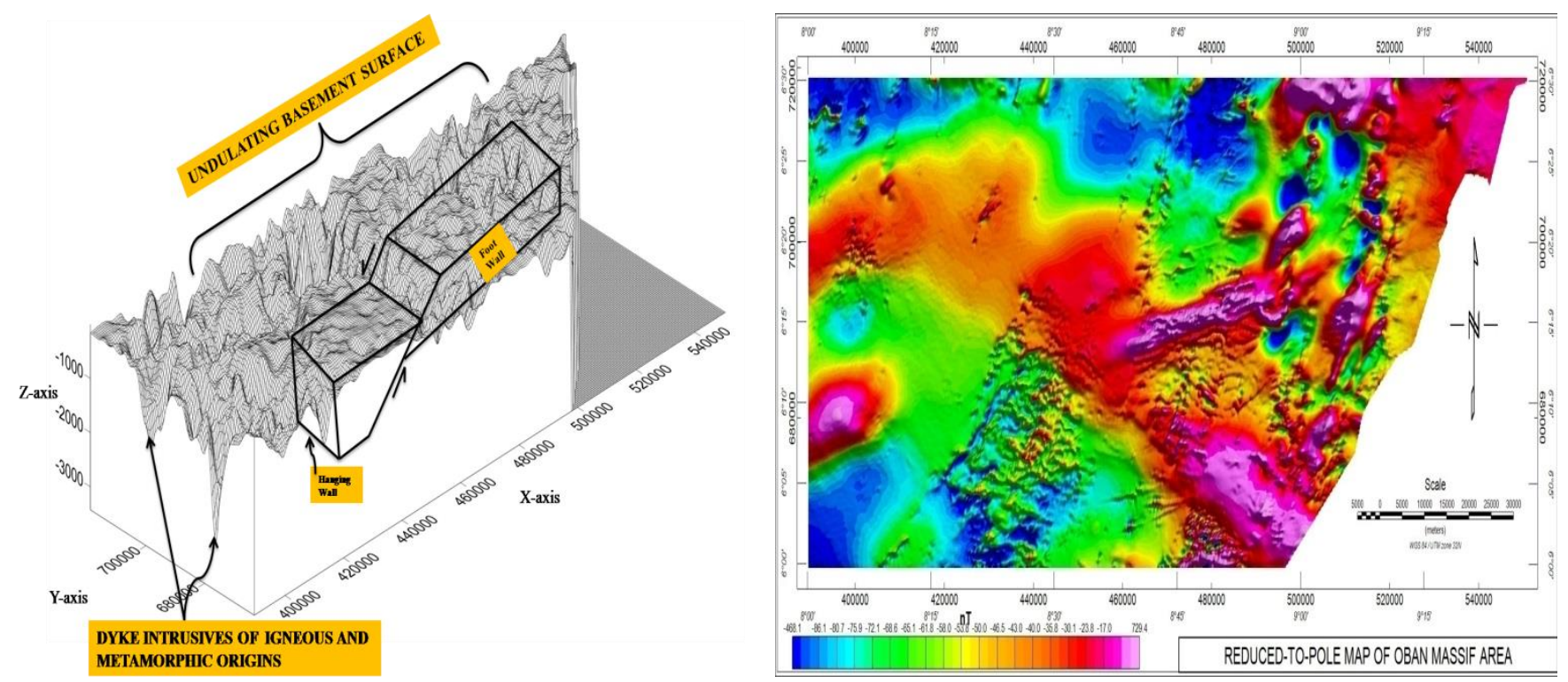

Fig.8. A juxtaposed section of 3-D model of subsurface basement topography \& reduced to pole aeromagnetic map 


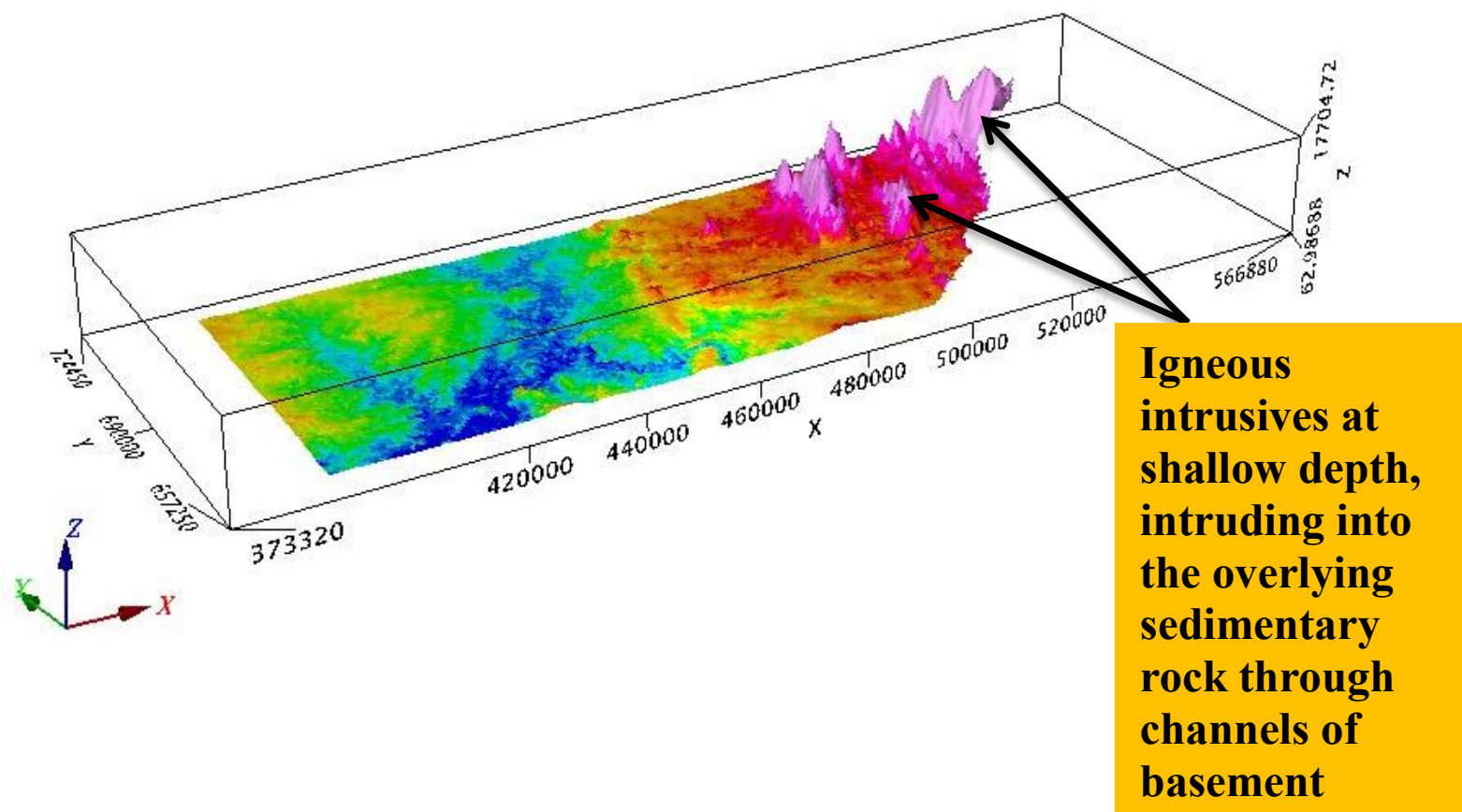

Fig.9. 3-D model of igneous intrusives at shallow depth

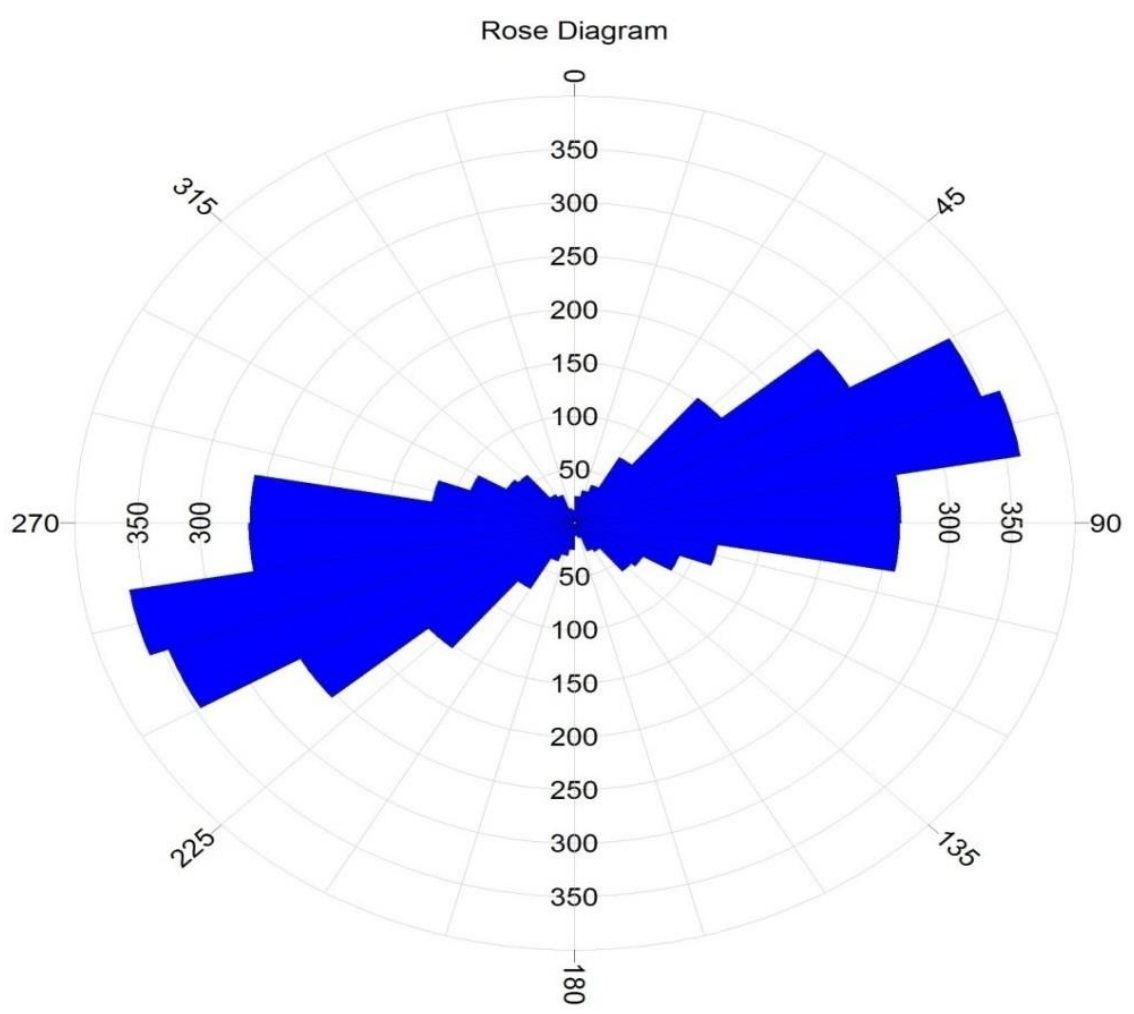

Fig.10. Rose diagram interpreted from magnetic data shows structural trends of major structures in NE-SW directions and minor structures in NW-SE directions due to subsurface deformational activities

\section{Conclusion}

Several zones across the study area were analysed to understand subsurface events that may be responsible for the changes in structural and magnetic anomalies. In this case, zone A is characterized around the northern part of the study area where the magnetic intensity contour lines range from 73-96.9nT with high amplitude anomalies. Zone 
B covers the south-western part of the study area that is characterised with broad and long wavelength anomalies which typifies that, a deep seated causative body could be responsible for the anomalous changes at depth. Thus, zone $\mathrm{C}$ displays numerous narrow shaped anomalies in the form of (volcanic pipes) and they are of high amplitude ranging from 50.2-61.9nT. The magnetic intensity contour lines range from 73.0nT - 88.7nT due to sporadic dikes of basic and ultrabasic origin and seem to cluster together. Furthermore, the north-eastern part of zone D shows the presence of granitic rocks that are Pan-African in Age. This is believed to be formed from volcanic igneous intrusives from basement rocks that are near surface. The intrusives have an average dip of $54.2^{0}$ with depth to basement surface ranging from $0.102 \mathrm{~km}-0.549 \mathrm{~km}$. The towns associated in this zone are Boji which is few kilometers West of Kanyang and some kilometers south of Ubong in the northeastern part of the area. The rock types formed by basic intrusives are diorite, biotite granite and dolerite.

\section{Declarations}

\section{Source of Funding}

This research did not receive any grant from funding agencies in the public, commercial, or not-for-profit sectors.

\section{Competing Interests Statement}

The authors declare no competing financial, professional and personal interests.

\section{Consent for publication}

Authors declare that they consented for the publication of this research work.

\section{Availability of Data}

The data was obtained from the Nigerian Geological Survey Agency (NGSA), and all required data are available within this manuscript itself.

\section{References}

[1] Ekwueme, B.N. (2003). The Precambrian Geology and Evolution of South eastern Nigerian Basement Complex. University of Calabar press, 135-140.

[2] David, I.I. \& Marius, N.U. (2013). Interpretation of Aeromagnetic Anomalies over Some Parts of Lower Benue Trough Using Spectral Analysis Technique. International J. of Scientific and Technology Research, 2(8): 153-165.

[3] Goodhope, A. \& Luke M. (2013). Structural Interpretation of Abakiliki - Ugep, using Airborne Magnetic and Landsat Thematic Mapper (TM) Data. Department of Geology University of Nigeria, Nsukka, Enugu State Nigeria. Journal of Natural Sciences Research, 3(13): 137-148.

[4] Ukaigwe, N.F. (2000). A First Course in Seismic Exploration. pp. 417.

[5] Ukaigwe, N. F. (1997). Digital Geophysical Data Processing (Theory and Applications). pp. 247-302.

[6] Ephraim, B.E., Ekwueme, B.N. \& Adamu I.C. (2006). Petrology of the northeastern region of Obudu Plateau, Bamenda Massif, southeastern Nigeria. Global Journal of Geological Series, 4(2): 109-119. 
Asian Journal of Basic Science \& Research

Volume 3, Issue 4, Pages 61-71, October-December 2021

[7] Wright, E.P. (1971). Basement Complex. In Geology of the Jos Plateau. Bulletin, Geological Survey of Nigeria, 32 (1): 619 p.

[8] Ferre, E., Gleizes, G., Bouchez, J.L. \& Nnabo, P.N. (1995). Internal fabric and strike-slip emplacement of the Pan African granite of Solli Hills, northern Nigeria. Tectonics, 14: 1205-1219.

[9] Ferre, E., Deleris, J., Bouchez, J.L., Lar, A.U. \& Peucat, J.J. (1996). The Pan Africa reactivation of the Eburnean and Archaean Provinces in Nigeria structural and isotopic data. Journal of geological society of London, 153: 719-728.

[10] Bowden, P. \& Kinnaird, J.A. (1984). The petrology and geochemistry of alkaline granites from Nigeria. Physics of Earth and Planetary interiors. 35: 199-211.

[11] Rahaman, A.A.M. S., Ukpong, E.E. \& Azmatullah, M. (1981). Geology of parts of the Oban Massif South-eastern Nigeria. Journal of Mining Geology, 18 (1): 60-65.

[12] Ekwueme, B.N. \& Ekwere, S.J. (1989). The petrology of the eastern section of the Oban Massif. SE Nigeria. Journal of Mining and Geology. 25: 317-329.

[13] Ekwere, S.J. \& Ekwueme, B.N. (1991). Geochemistry of Precambrian gneisses in the Eastern part of the Oban massif, SE Nigeria. Geol. Min, 70: p. 195-114.

[14] Ekwueme, B.N. \& Kroener (1998). Single zircon evaporation ages from Oban Massif, southeastern Nigeria. Journal of African Earth Sciences. 26 (2) 195-205.

[15] Orajaka, S. (1964) Geology of the Southern Obudu Plateau, Ogoja Province,Eastern Nigeria. Le Nataraliste Canadian XCI (3). 72 -86.

[16] Umeji, A.C. (1991) Petrology and geochemistry of monzagranites from Jato Aka and their significance to platonism in the Pan-African belt of Nigeria [J]. J. Min. Geol. 27, 115 -127.

[17] Ekwueme, B.N. (1990) Petrology of Southern Obudu Plateau, Bamenda Massif, Southeastern Nigeria. In Recent Data in African Earth Sciences (eds. G. Rocci and M. Deschamps). CIFEG Occasional Pub. 22, 155-158.

[18] Ekwueme, B.N. (1994a) Basaltic magrrmtism related to the early stages of rifting along the Benue Trough : The Obudu dolerites of southeast Nigeria [ J ]. Geological Journal. 29, 269 - 276.

[19] Ekwueme, B.N. (1998) Geochemistry of Precambrian gneisses of the Southern Obudu Plateau, southeastern Nigeria [ J ]. Global Journ. Pure Applied Science. 4, 277 - 282.

[20] Ejimofor, O.C., Umeji, A.C. \& Turaki, U.M. (1996) Petrography and major element geochemistry of the basement rocks of northern Obudu area, Eastern Nigeria [J]. Journ. Mining and Geol. 32, 1-9.

[21] Orajaka, S.O. (1971). The petrogenesis of the Obudu type enderbite. J. of Mines, Metals and Fuels, pp. 94-98. [22] Ekwueme, B.N. (1991). Geology of the area around Obudu cattle ranch. Southeastern Nigeria, Journal of Mining and Geology, 27: 129-134.

[23] Ekwueme, B.N. (1994b). Structural features of Southern Obudu Plateau, Bamenda massif SE, Nigeria: Preliminary interpretations. Journal of Mining Geology, 30(1): 45-59. 
[24] Ephraim, B.E. (2005). Petrology and geochemistry of basement complex rocks Northeast of Obudu, Bamenda Massif, Southeastern Nigeria. Unpublished PhD thesis, University of Calabar, Calabar, 350p.

[25] Ekwueme, B.N. \& Kroener (1997). Zircon evaporation ages and chemical composition of migmatitic schist in the Obudu Plateau: evidence for Paleooproterozoic (ca. 1789) components in the basement complex of southeastern Nigeria. Journal of Mining and Geology, 33 (2): 81-88.

[26] Ekwueme, B.N. \& Kroener (2000). Single zircon evaporation ages from Obudu Plateau, first evidence of Archaean components in the schists of southeastern Nigeria. 36th Annual Conference of Nigerian Mining and Geosciences Society (Enugu Nigeria). Abstract Vol. 14.

[27] Ekwueme, B.N. \& Kroener (2001). Timing of granulite facies metamorphism in the Obudu Plateau, Southeastern Nigeria. 37th Annual Conference of Nigerian Mining and Geosciences Society (Jos, Nigeria) Abstract, Vol., 32.

[28] Ukwang, E.E., Ekwueme, B.N. \& Horsley, R.J. (2003). Petrology of granulite facies rocks in Ukwortong area of Obudu Plateau, southeastern Nigeria. Global Journal of Geological Sciences.1 (2): 159-167.

[29] Obiora, S.C. (2012). Chemical Characterization and Tectonic Evolution of Hornblende-Biotite Granitoids from the Precambrian Basement Complex around Ityowanye and Katsina-Ala, southeastern Nigeria. Journal of Mining and Geology, vol. 48 (1), pp. 13-29.

[30] Ekwueme, B.N., Eyo, E.N. \& Sunday, W.P. (1995). Geological Excursion Guide to Oban Massif, Calabar Flank and Mamfe Embayment, Southeastern Nigeria. The 31st Annual Conference of the Nigeria Mining and Geosciences Society, Calabar, Nigeria. 1-36.

[31] Dobrin, M.B. \& Savit, C.H. (1988). Introduction to geophysical prospecting. 4th Ed., McGraw-Hill NY, 867p. [32] Telford, W.M., Geldart, L.P. \& Sheriff, R.E. Applied Geophysics 1990. University of Cambridge Press.

[33] Alain, N.S.F., Theophile, N.M., Eliezer, M.D. \& James, D.F. (2012). Delineation of tectonic lineaments using aeromagnetic data for the south-east Cameroon area. University of Yaoundé, faculty of Science, Department of Physics, Yaoundé, Cameroon. Geofizika, 29(2) 175-192.

[34] Alain, Z.A., Théophile, N.M., Arsène, M., Donatius, Y. L., Marcellin, B.B. \& Eliezer, M.D. (2013). 2-D Modeling of Crustal Structures along the Eastern Cameroon and Western Central African Republic Derived from Finite Element and Spectral Analysis Methods. Department of Physics, Faculty of Science, University of Douala, Douala, Cameroon. Geophysical Journal, 49(1) 75-97.

[35] Adetona, A.A. \& Abu, M. (2013). Estimating the thickness of sedimentation within Lower Benue Basin and Upper Anambra Basin, Nigeria, using both spectral depth determination and source parameter imaging. Geo., 1-10. [36] Thompson, D.T. (1982). EULDPH: A new technique for making computer assisted depth estimates from magnetic data. Geophysics 47(1): 32-38.

[37] Reid, A.B., Allsop, J.M., Granser, H., Millet, A.J. \& Somerton, I.W. (1990). Magnetic interpretation in three dimensions using Euler devolution. Geophysics, 55(1): 80-91. 